\title{
Mesenchymal stem cell conditioned medium alleviates oxidative stress injury induced by hydrogen peroxide via regulating miR143 and its target protein in hepatocytes
}

Xuejing $\mathrm{Xu}^{1,2+}$, Dong $\mathrm{Li}^{2+}$, Xue Li ${ }^{2}$, Qing Shi ${ }^{2}$ and Xiuli Ju $\mathrm{Ju}^{1,2^{*}}$

\begin{abstract}
Background: To investigate the impact of miRNA (microRNA) on hepatic oxidative stress damage under the human mesenchymal stem cell conditioned medium (MSC-CM) and explore the roles of the beta-1 adrenergic receptor (ADRB1) and hexokinase 2 (HK2) in this process.

Methods: Hydrogen peroxide was used to induce oxidative stress injury in the human normal liver cell line L02. MSC-CM was separately prepared. After treatment with MSC-CM, the protective effects of MSC-CM on oxidative stress injury were assessed by changes in apoptosis, cell viability, cell cycle, and mitochondrial membrane potential. According to the microarray analysis, 19 disparately expressed miRNAs were selected for RT-PCR and miR143 identified as having significant differential expression in MSC-CM against oxidative stress injury. Subsequently, the predicted target proteins of miR143 were selected by bioinformatics software, and verified by western blot. In addition, down-regulation and up-regulation of miR143 expression and hydrogen peroxide induced hypoxia injury were carried out on L02 cells to study the role of miR143.

Results: MSC-CM significantly attenuated $\mathrm{H}_{2} \mathrm{O}_{2}$ induced oxidative stress injury. The expression of miR143 was increased following oxidative stress injury whereas it decreased after MSC-CM treatment. The expression levels of HK2 and ADRB1 regulated by miR143 and BCl-2 decreased under $\mathrm{H}_{2} \mathrm{O}_{2}$ treatment but were restored following MSC-CM treatment. However the expression levels of Bax and BMF increased after $\mathrm{H}_{2} \mathrm{O}_{2}$ injury and decreased after MSC-CM treatment. Moreover over-expression or down-regulation of miR143 aggravated or alleviated hepatocyte apoptosis respectively.
\end{abstract}

Conclusions: MSC-CM may alleviate $\mathrm{H}_{2} \mathrm{O}_{2}$ induced oxidative stress injury by inhibiting apoptosis and adjusting miRNA expression. Moreover down-regulation of miR143 protects L02 cells from apoptosis and initiates an adaptive process by adjusting the expression of HK2 ADRB1 and apoptosis-related proteins.

Keywords: Hepatocyte, Oxidative stress injury, Mesenchymal stem cell, miRNA, Apoptosis

\footnotetext{
*Correspondence: jxlqlyy@163.com

†Equal contributors

${ }^{1}$ Shenzhen Research Institute of Shandong University, Shenzhen 518057,

China

${ }^{2}$ Department of Pediatrics, Qilu Hospital, Shandong University, Jinan 250012,

China
} 


\section{Background}

Oxidative stress injury leads to severe local and remote tissue injury and subsequent distant organ functional failure, including that of the gastrointestinal tract, cardiovascular system, brain, and liver [1-4]. The mechanisms of hypoxia are mainly derived from cellular damage $[5,6]$. Until now, no effective therapeutic protocol has been proven to modify the course of oxidative stress injury.

Substantial previous work has demonstrated that mesenchymal stem cells (MSCs) have notable capability to repair ischemic organ tissue [7]. Studies have shown that MSC conditioned medium (MSC-CM) is a promising novel therapeutic agent to promote proliferation and antiapoptotic and anti-inflammatory responses after acute organ injury [8-13]. The rationale for MSC therapy is increasingly recognized to act by a secretion (paracrine) rather than differentiation mechanism [14-16].

MicroRNAs (miRNAs) play critical roles to regulate differentiation, paracrine activity, and other cellular activities [17]. MiRNAs are small non-coding RNA molecules that affect mRNA stability and translation, which play a key role in mediating biological function due to their prominent role in gene regulation. Mature miRNAs are important for numerous cellular processes and deregulation of miRNAs can be observed in several pathological processes [18]. Until now, despite the extensive and increasing knowledge regarding the regulation of miRNAs, little is known about the expression change of miRNAs in hepatocytes during the MSC-CM mediated apoptosis rescue process. In the present study, we demonstrate that MSC-CM is able to ameliorate hepatocyte injury. Nineteen chip hybridization-screened miRNAs were verified to show significant changes in expression during this process, from which miR143 was verified by quantitative PCR. The predicted target proteins of miR143, HK2 and ADRB1, were analyzed by three bioinformatics algorithms, and verified by western blot. We also downregulated and up-regulated miR143 expression to study the effect of miR143 on apoptosis, cell cycle, mitochondrial membrane potential (MMP), and cell viability in L02 cells.

\section{Methods}

\section{Culture of human umbilical-cord-derived MSCs}

Human umbilical cord was obtained from healthy donors at the Department of Obstetrics in Shandong University Qilu Hospital, Jinan, China. Umbilical cords were dissected to remove blood vessels and cut into small fragments. Then, human umbilical-cord-derived MSCs (hUC-MSCs) were cultured in $\alpha$-minimum essential medium ( $\alpha$-MEM; Gibco; Thermo Fisher Scientific, Waltham, MA, USA) with $10 \%$ fetal bovine serum (FBS; Gibco) supplemented with $100 \mathrm{U} / \mathrm{mL}$ penicillin and $100 \mu \mathrm{g} / \mathrm{mL}$ streptomycin (Gibco). Cultures were maintained at $37{ }^{\circ} \mathrm{C}$ in a humidified atmosphere of $5 \% \mathrm{CO}_{2}$ in air. The culture medium was changed every 3-4 days. The MSCs used throughout this study were between passage 3 and 6 .

\section{Identification and differentiation of hUC-MSCs and prep- aration of MSC conditioned medium}

Flow cytometry analysis was performed to characterize MSCs according to the previously study [19]. The hUCMSCs were analyzed for their ability to differentiate into adipocytes and osteoblasts as described previously [20]. The cells used were between passage 5 and 7 .

Once the MSCs reached 70-80\% confluency, the medium was replaced with fresh full medium and harvested after $24 \mathrm{~h}$. Subsequently, MSC-CM were centrifuged at $2500 \mathrm{rpm}$ for $20 \mathrm{~min}$ with $0.1-\mu \mathrm{m}$ filtration to remove detached MSCs and cell debris.

\section{L02 cell culture and processing}

The human hepatic cell line L02 [21] was purchased from the Cell Resource Center of the Shanghai Institutes for Biological Sciences, Chinese Academy of Sciences (Shanghai, China). L02 cells were cultured in RPMI-1640 medium (Gibco) with 20\% FBS (Gibco),100 U/mL penicillin, $100 \mu \mathrm{g} / \mathrm{mL}$ streptomycin (Gibco), and $10 \mu \mathrm{g} / \mathrm{mL}$ insulin (Wanbang, Jiangsu, China) at $37{ }^{\circ} \mathrm{C}$, in a $5 \% \mathrm{CO}_{2}$ incubator [21]. Subsequently, the L02 cells were cultured to 70-80\% confluency before exposure to $1 \mathrm{mM}$ hydrogen peroxide $\left(\mathrm{H}_{2} \mathrm{O}_{2}\right.$, DAMAO, Tianjin, China. $)$ for $3 \mathrm{~h}$ to induce oxidative stress injury. In detail, L02 were randomly divided into the following three groups: the normal control group (Control) with normal incubation, the $\mathrm{H}_{2} \mathrm{O}_{2}$ treatment group $\left(\mathrm{H}_{2} \mathrm{O}_{2}\right)$ which were incubated with $1 \mathrm{mM} \mathrm{H}_{2} \mathrm{O}_{2}$ for $3 \mathrm{~h}$ in the above medium, and the rescue group with addition of 20\% MSC-CM for 6, 24, and $48 \mathrm{~h}$ following $\mathrm{H}_{2} \mathrm{O}_{2}\left(\mathrm{H}_{2} \mathrm{O}_{2}+\right.$ MSC-CM). Cell Counting Kit-8 (CCK-8; DOJINDO, Kyushu, Japan) was used to find the MSC-CM optimal time, which was determined to be $24 \mathrm{~h}$. All cell experiments were replicated a minimum of five times.

\section{Apoptosis, cell cycle, and MMP detection by flow cytometry}

To assess apoptosis, flow cytometry with AnnexinV/Propidium iodide (PI) double staining (BD Biosciences, New Jersey, United States) was used. Cell cycle stage (70\% ethanol fixed $12-24 \mathrm{~h}$ at $4{ }^{\circ} \mathrm{C}$ ) and MMP were also evaluated by flow cytometry with Propidium iodide (PI) staining (Beyotime, Shanghai, China) and JC-1 staining (1st J-aggregate-forming cationic dye; BD Biosciences), following the manufacturer's instructions. Apoptosis, cell cycle stage, and MMP were detected using flow cytometry (Millipore, Billerica, MA) and the data were analyzed using Guava Incyte (version 2.8; EMD Millipore). 


\section{Quantitative RT-PCR analysis of miRNAs and miR143 selection}

SD rats were purchased from the Experimental Animal Centre of Shandong University and housed in a specific pathogen-free (SPF) animal facility. Hepatic cirrhosis in SD rats was induced with carbon tetrachloride subcutaneous injection and alcohol oral administration. hUCMSCs or PBS were transplanted by intravenous injection once per week for 4 weeks. In detail, rats were randomly divided into the following three groups: normal rats (Nor) with PBS, cirrhotic rats $(\mathrm{CTr})$, and cirrhotic rats with MSC (MSC). The gene expression alterations were calculated between the PBS and MSC groups by miRNA microarray analysis.

Liver total RNA was harvested using TRIzol (Invitrogen) and the miRNeasy mini kit (QIAGEN) according to the manufacturer's instructions. After quantification using the NanoDrop 1000, the samples were labeled using the miR$\mathrm{CURY}^{\mathrm{TM}} \mathrm{Hy} 3^{\mathrm{TM}} / \mathrm{Hy} 5^{\mathrm{TM}}$ Power labeling kit and hybridized on the miRCURY ${ }^{\mathrm{m}}$ LNA Array (v.18.0). Following the washing steps, the slides were scanned using the Axon GenePix 4000B microarray scanner.

Scanned images were then imported into GenePix Pro 6.0 software (Axon) for grid alignment and data extraction. miRNA replicates were averaged and the normalization factor calculated for miRNAs with intensities $\geq 30$ in all samples. Expressed data were normalized using the median normalization. After normalization, differentially expressed miRNAs were identified through Fold Change filtering. Finally, hierarchical clustering was performed to show distinguishable miRNA expression profiling among samples.

Nineteen disparately expressed miRNAs (Additional file 1) were selected by gene chip hybridization in the model of cirrhotic rats treated with MSC. miRNA was extracted from the L02 cells, which were treated with MSC-CM for $24 \mathrm{~h}$ after $1 \mathrm{mM} \mathrm{H}_{2} \mathrm{O}_{2}$ treatment for $3 \mathrm{~h}$ using the miRcute miRNA Isolation Kit (Tiangen, Beijing, China) according to the manufacturer's instructions. To verify the expression of the specific miRNAs in the process of $\mathrm{H}_{2} \mathrm{O}_{2}$ injury and the protective effect of MSC-CM, RT-PCR was performed on the 19 disparately expressed miRNAs described above.

First-strand cDNA of miRNA was synthesized using $0.25 \mu \mathrm{l}$ of miRNA in a $20 \mu \mathrm{l}$ reverse transcriptase reaction mixture using the miRcute miRNA First-Strand cDNA Synthesis Kit (Tiangen) with miRNA specific primers (Tiangen). Using the miRcute miRNA qPCR Detection (SYBR Green) kit (Tiangen), quantitative RTPCR was performed with the ABI Prism 7500 sequence detection system. The miRNA expression levels were normalized to those of U6. Data were analyzed using Sequence Detection Software (Version 1.4, Applied Biosystems, Carlsbad, CA). The relative quantity of the transcript was calculated using $2^{-\Delta \mathrm{Ct}}$ the method, where $\Delta \mathrm{Ct}=\mathrm{Ct}_{\text {miRNAtest }}-\mathrm{Ct}_{\text {miRNActr. }}$.

\section{Bioinformatics of miR143}

We used three algorithms, namely miRBase (http:// www.mirbase.org/), TargetScan (http://www.targetscan.org/), and PicTar (http://pictar.mdc-berlin.de/) to predict the corresponding downstream target genes of the miRNA143.

\section{Cell transfection and miR143 treatment}

To study the effect of miRNA143 in oxidative stress injury, we up- and down-regulated miRNA143 by transfecting miR143 mimics, miR143 inhibitors, a negative control (NC), or an miRNA inhibitor negative control (inhibitor NC, GenePharma). One day before transfection, L02cells were plated in 24-well plates without antibiotics so that they would be $30-50 \%$ confluent at the time of transfection. Cells were transfected with $33 \mathrm{nM}$ miRNA oligomer using Lipofectamine 2000 (Invitrogen) according to the manufacturer's instructions; the culture medium was replaced at 6 and $36 \mathrm{~h}$ after miRNA transfection. After $36 \mathrm{~h}$ of transfection, the cells were used for RT-PCR. The RT-PCR analysis demonstrated that miR143 inhibitors significantly down regulate miR143 expression in L02 cells compared with inhibitor NC and NC. On the other hand, miR143 mimics significantly up regulated miR143 expression, and there was no difference between inhibitor $\mathrm{NC}$ and NC. According to the analysis of RT-PCR, miR143 was transfected and differently expressed into L02 cell successfully (Fig. 6c).

L02 cells were incubated at $37{ }^{\circ} \mathrm{C}$ for 36,48 , and $60 \mathrm{~h}$. CCK8 was used to find miR143 transfected time. CCK-8 was used to detect cell proliferation. Briefly, after transfection with miR143 mimics, inhibitors, or scrambled oligonucleotides (miRNA negative control-NC and miRNA inhibitor NC; 33 nM; Gene Pharma, Shanghai, China) using Lipofectamine 2000 (Invitrogen, Carlsbad, CA), the cells were incubated with $0.8 \mathrm{mM} \mathrm{H}_{2} \mathrm{O}_{2}$ for $2 \mathrm{~h}$, then $10 \mu \mathrm{l} \mathrm{CCK-8}$ was added. After $2-3 \mathrm{~h}$, the optical density (OD) was measured with a microplate reader (KeyGen, NanJing, China) at $450 \mathrm{~nm}$ using the following formula: $\mathrm{OD}_{\text {experiment }}$ - $\mathrm{OD}_{\text {blank }}$ (blank control group: no cells and medium). According to the analysis of CCK8, the optimal miR143 transfection time was $60 \mathrm{~h}$. All cell experiments were replicated a minimum of five times.

Subsequently the cells were treated with $0.8 \mathrm{mM} \mathrm{H}_{2} \mathrm{O}_{2}$ for $2 \mathrm{~h}$. Apoptosis, cell cycle, cell viability, MMP, and western blot analysis were performed for recovery following $\mathrm{H}_{2} \mathrm{O}_{2}$ injury.

\section{Western blotting}

L02 cell lysates ( $1 \mu \mathrm{g} / \mu \mathrm{l}$, Beyotime) were prepared using RIPA buffer containing protease inhibitor PMSF (1 mM,Beyotime). Total proteins were separated by $12 \%$ SDS-PAGE. The proteins were then transferred onto polyvinylidene difluoride membranes (Millipore, USA). After blocking with $0.5 \%$ skimmed milk powder 
solution for $70 \mathrm{~min}$ at room temperature, proteins were detected by western blotting with the indicated antibodies overnight. Antibodies against HK2 (1:1000, Cat: 60,004-1-lg), Bcl-2 (1:1000, Cat: 12,789-1-AP), and Bax (1:2000, Cat: 60,267-1-lg) were purchased from Proteintech (Wuhan, China), antibodies against ADRB1 (1:1000, ab3342) and recombinant human Bcl2 modifying factor (BMF, 1:500, ab181148) were purchased from Abcam (Cambridge, MA USA). After washing with TBST, the membranes were incubated with secondary antibodies (1:10,000, Goat Anti-Mouse IgG $(\mathrm{H}+\mathrm{L})$, Cat: SA00001-1; 1:10,000, Goat Anti-Rabbit IgG $(\mathrm{H}+\mathrm{L})$, Cat: SA00001-2; proteintech) and developed using ECL (Millipore, Billerica, MA). The quantified densitometric analysis was performed using the UVP BioSpectrum multispectral imaging system (UltraViolet Products Ltd., Upland, CA, USA). The relative levels of the proteins were then determined by measuring the intensity of the corresponding bands. All the western-blot analyses were repeated a minimum of five times and the values were normalized to the constitutive expression of GAPDH.

\section{Statistical analysis}

Quantitative data are presented as the mean \pm standard deviation of a minimum of five independent replicates for of $\mathrm{H}_{2} \mathrm{O}_{2}$ injury, MSC-CM treatment, and miR143 transfection. For comparisons between miR143 mimics and inhibitor group under $\mathrm{H}_{2} \mathrm{O}_{2}$ injury, independent two sample $t$-tests were performed. For comparisons among the various cell lines, one-way analysis of variance (ANOVA) with Tukey-Kramer postdoc analysis was employed. Differences between the values were considered to be significant at $P<0.05$. All the statistical analysis were carried out with SPSS 20.0 software program (SPSS, Inc., Chicago, IL, USA) and graphs were made using GraphPad Prism 6 (Beijing, HuanZhongRuiChi).

\section{Results}

\section{In vitro differentiation of hUC-MSCs}

For osteogenic differentiation, the cells were cultured for 20 days in osteogenic medium. Calcium precipitation, determined by alkaline phosphatase and Alizarin Red S staining, was observed in the hUC-MSCs (Fig. 1a-b). Adipogenic differentiation of hUC-MSCs was apparent after 14 days. Oil Red O-positive lipid droplets were observed (Fig. 1c-d).

\section{Protective effect of MSC-CM on apoptosis of L02 cells exposed to $\mathrm{H}_{2} \mathrm{O}_{2}$}

To quantify the effects of MSC-CM (20\% MSC-CM for $24 \mathrm{~h}$ ) on $\mathrm{H}_{2} \mathrm{O}_{2}$-induced ( $1 \mathrm{mM} \mathrm{H}_{2} \mathrm{O}_{2}$ for $3 \mathrm{~h}$ ) cell apoptosis and necrosis, we performed flow cytometry with AnnexinV/PI double staining, which was used to discriminate apoptosis from necrotic cells, JC-1 was employed to detect MMP $(\Delta \psi)$, PI single staining was applied to detect cell cycle and CCK-8 analysis was applied to demonstrate that the MSC-CM could prevent L02 cell from undergoing apoptosis. According to Annexin V/PI flow cytometry analysis (Fig. $2 \mathrm{a}-\mathrm{b}, P<0.05$ ), the percent of typical apoptotic cells reached $31.6 \% \pm 1.07 \%$ and $15.58 \% \pm 0.55 \%$ in the $\mathrm{H}_{2} \mathrm{O}_{2}$ and $\mathrm{H}_{2} \mathrm{O}_{2}+$ MSC-CM groups respectively, while
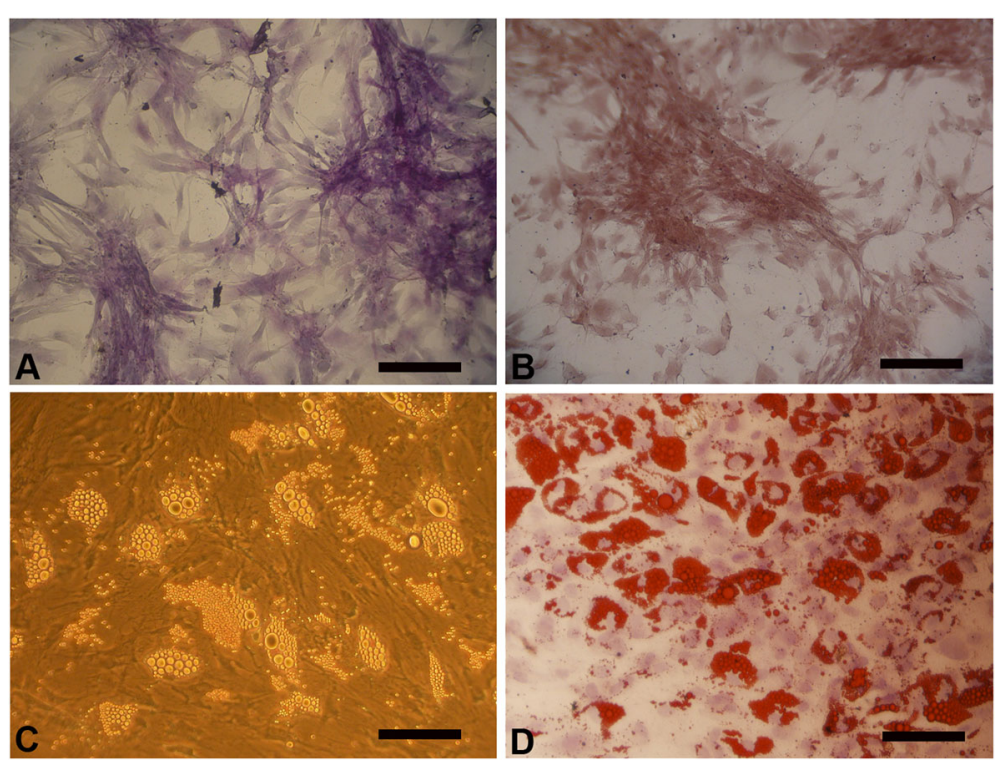

Fig. 1 Differentiation of hUC-derived MSCs. Osteogenic differentiation of MSCs was demonstrated by the formation of calcium-hydroxyapatite-positive areas stained in red by Alizarin Red (a) and brown by alkaline phosphatase (b). Adipogenic differentiation was demonstrated by intracellular lipid vacuoles stained in red by Oil Red O (c-d). Scale bar $=100 \mu \mathrm{m}$ 

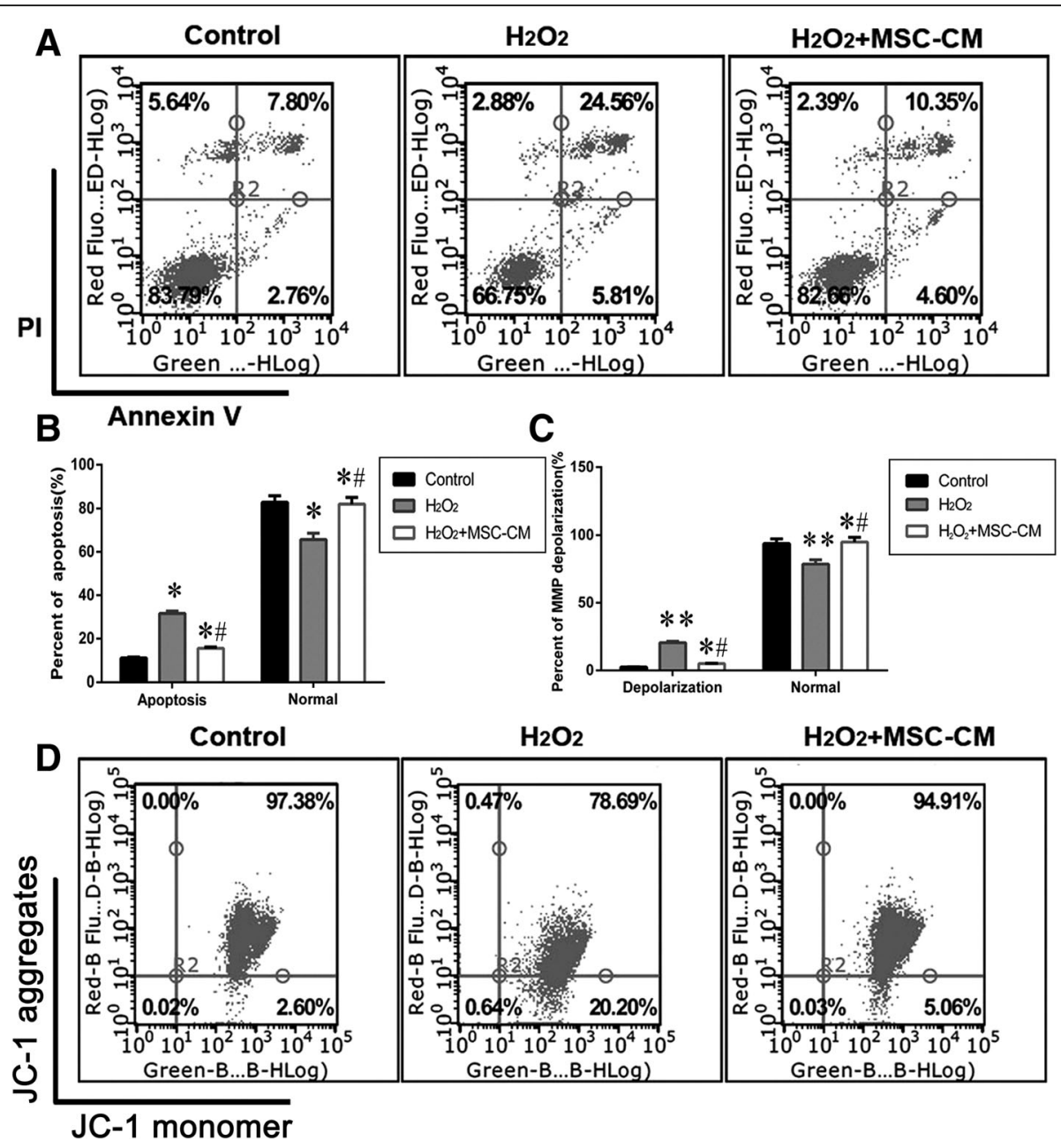

Fig. 2 MSC-CM treatment decreases apoptosis. $\mathrm{H}_{2} \mathrm{O}_{2}$ : $\mathrm{LO} 2$ incubated with $1 \mathrm{mM} \mathrm{H}_{2} \mathrm{O}_{2}$ for $3 \mathrm{~h} ; \mathrm{H}_{2} \mathrm{O}_{2}+\mathrm{MSC}-\mathrm{CM}$ : rescue group with addition of $20 \%$ MSC-CM for $24 \mathrm{~h}$ following $\mathrm{H}_{2} \mathrm{O}_{2}$ injury. a. MSC-CM protects LO2 cells from apoptosis examined by Annexin V/PI double staining and flow cytometry. b The percentage of apoptotic L02 cells in the total cell population. c-d. MSC-CM protects L02 cells from MMP depolarization examined by JC-1 staining and flow cytometry. The lower right quadrant: MMP depolarization, a sign of early apoptosis (Mean \pm SD. $n=10 .{ }^{*} P<0.05$ and ${ }^{* *} P<0.01$ vs. control group; $\# P<0.05$ vs. $\mathrm{H}_{2} \mathrm{O}_{2}$ group)

the apoptosis rate of the control group was $11.04 \% \pm$ $0.39 \%$. Compared with the $\mathrm{H}_{2} \mathrm{O}_{2}$ group, the apoptosis rate of normal cells increased by $16.31 \% \pm 3.26 \%$ $(65.69 \% \pm 2.91 \%$ vs. $82.00 \% \pm 3.11 \%$, Fig. $2 \mathrm{a}-\mathrm{b}, P<0.05)$ in the $\mathrm{H}_{2} \mathrm{O}_{2}+\mathrm{MSC}-\mathrm{CM}$ group. In addition, the percentage of apoptotic cells whose MMP decreased visualized by JC-1 staining clearly increased after $\mathrm{H}_{2} \mathrm{O}_{2}$ stimulation, and was restored after MSC-CM treatment (Fig. 2c-d, $P<0.05$ ).

The Bcl-2 family plays a role in the regulation of apoptosis and mitochondrial membrane potential. To address whether $\mathrm{H}_{2} \mathrm{O}_{2}$ injury and the protective role of MSC-CM also influence the $\mathrm{Bcl}-2$ family proteins, the western blotting of $\mathrm{Bax}, \mathrm{Bcl}-2$, and $\mathrm{BMF}$ were assessed for the control, $\mathrm{H}_{2} \mathrm{O}_{2}$ and $\mathrm{H}_{2} \mathrm{O}_{2}+$ MSC-CM groups. Our results showed that $\mathrm{H}_{2} \mathrm{O}_{2}$ decreased the Bcl-2/Bax ratio significantly in comparison with the control, while
MSC-CM remarkably restored this ratio. Consistent with $\mathrm{H}_{2} \mathrm{O}_{2}$-dependent apoptosis activation, BMF expression was markedly increased in the $\mathrm{H}_{2} \mathrm{O}_{2}$ group, while it was low in the control group. However, BMF expression was significantly lower in the MSC-CM group compared to that in the $\mathrm{H}_{2} \mathrm{O}_{2}$ group (Fig. 3, $P<0.05$ ).

\section{Protective effect of MSC-CM on proliferation and cell cycle of $\mathrm{LO2}$ cells exposed to $\mathrm{H}_{2} \mathrm{O}_{2}$}

$\mathrm{H}_{2} \mathrm{O}_{2}$ induced injury significantly reduced L02 cell viability at 24 and $48 \mathrm{~h}$ as compared with the $\mathrm{H}_{2} \mathrm{O}_{2}+$ MSC$\mathrm{CM}$ group. Moreover, the cell viability of $\mathrm{H}_{2} \mathrm{O}_{2}$ group recovered to about $11.5 \% \pm 2.85$ and $15.8 \% \pm 2.79$ when MSC-CM was administered at 24 and $48 \mathrm{~h}$, respectively (Fig. 4a, $P<0.05$ ). As shown in Fig. $4 \mathrm{~b}-\mathrm{c}, \mathrm{H}_{2} \mathrm{O}_{2}$ injury also resulted in a marked increase in the percentage of the cell population in the G0/G1 phase and a sharp 


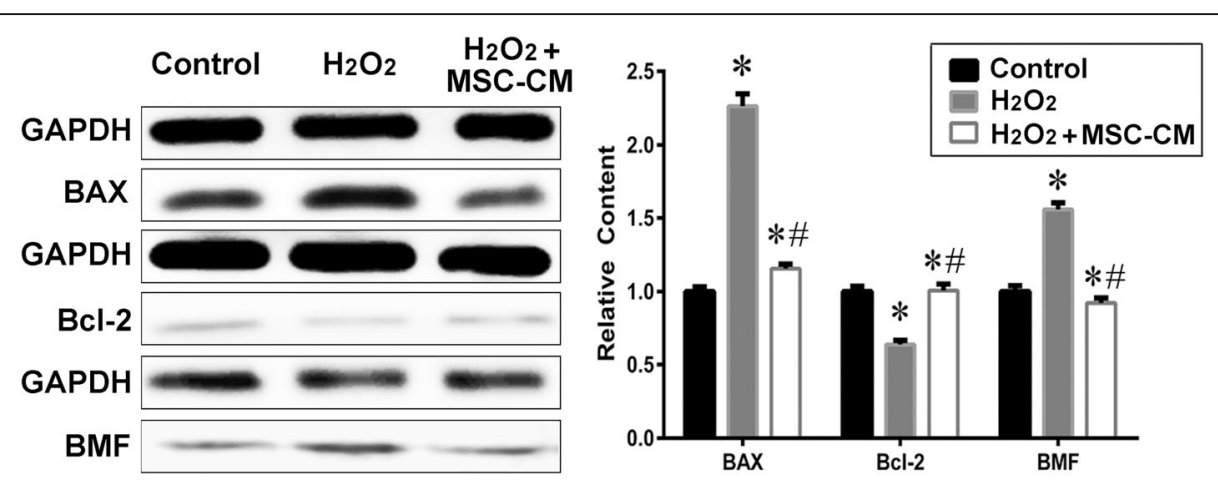

Fig. 3 Apoptosis-related protein relative content in $\mathrm{H}_{2} \mathrm{O}_{2}$ injury and MSC-CM treatment groups. Control group $=1$. Mean $\pm S D . n=10$. ${ }^{*} P<0.05$ vs. control group; $\# P<0.05$ vs. $\mathrm{H}_{2} \mathrm{O}_{2}$ group

decrease in the $\mathrm{S}$ and $\mathrm{G} 2 / \mathrm{M}$ phases, indicating that $\mathrm{H}_{2} \mathrm{O}_{2}$ injury induces cell cycle arrest of L02 cells at the $\mathrm{G} 1 / \mathrm{S}$ transition and the G1/S transition was pronouncedly disinhibited after treatment with MSC-CM (20\% MSC-CM for $24 \mathrm{~h}, P<0.05)$.

\section{Verification of miR143 and prediction of downstream target genes of miR143}

According to the microarray, we selected 19 disparately expressed miRNA (see Additional file 1) for RT-PCR. As shown in Fig. 5, miR143 level was significantly increased in the $\mathrm{H}_{2} \mathrm{O}_{2}$ group and decreased in the $\mathrm{H}_{2} \mathrm{O}_{2}+\mathrm{MSC}-\mathrm{CM}$ group. To further study the regulatory mechanism of miR143 in $\mathrm{H}_{2} \mathrm{O}_{2}$ injury, we used the bioinformatics tools miRbase, TargetScan, and PicTar to predict target genes. ADRB1 (beta-1-adrenergic receptor) and HK2 (Hexokinase 2) were identified as candidate target genes of miR143 and had the highest predicted context score percentiles and association with glycometabolism and inflammation regulation.
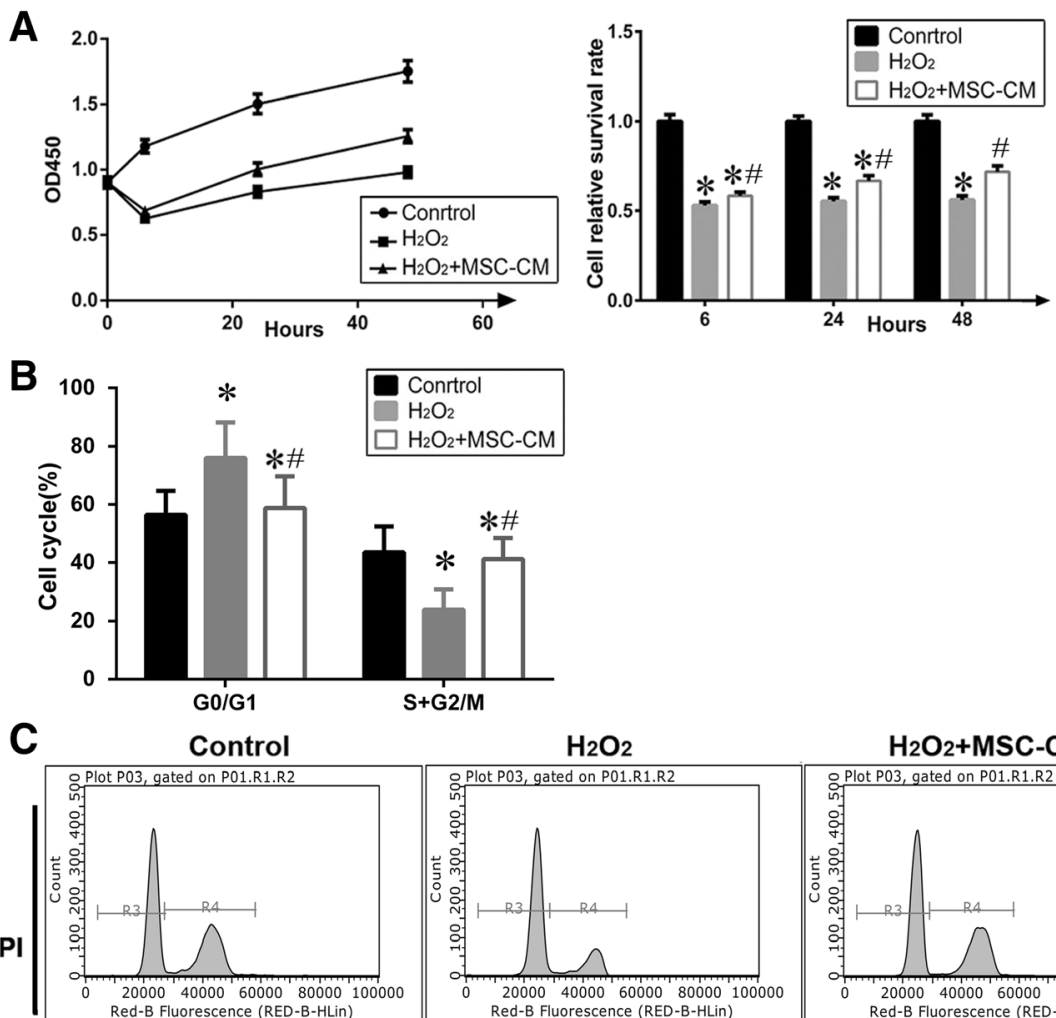

$\mathrm{H}_{2} \mathrm{O}_{2}+\mathrm{MSC}-\mathrm{CM}$

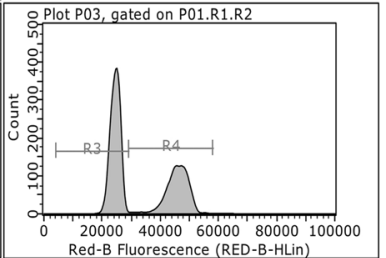

Fig. 4 MSC-CM promoted cell viability and regulated cell cycle of the $\mathrm{LO} 2$ cells with $\mathrm{H}_{2} \mathrm{O}_{2}$ injury. a. Effects of MSC-CM on cell viability and analysis. According to the analysis of CCK8, the optimal MSC-CM cultivated time was $24 \mathrm{~h}$. $(n=10$, Control group $=1)$. $\mathbf{b}-\mathbf{c}$. Cell cycle distribution in L02 cells and analysis. (Mean \pm SD. $n=10$. ${ }^{*} P<0.05$ vs. control group; $\#<<0.05$ vs. $\mathrm{H}_{2} \mathrm{O}_{2}$ group) 


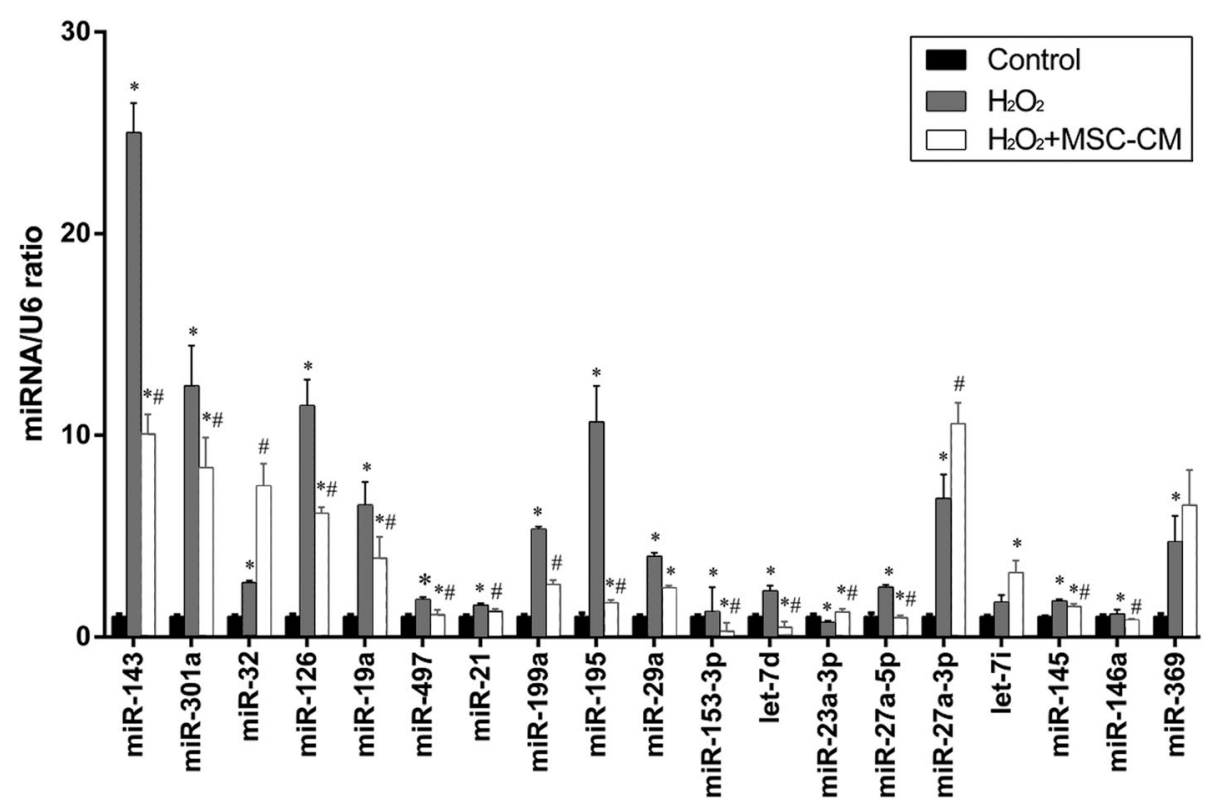

Fig. 5 miRNA expression in LO2 cells after $\mathrm{H}_{2} \mathrm{O}_{2}$ injury and MSC-CM treatment was validated by qRT-PCR. Control group $=1$. Mean $\pm S D, n=10$, ${ }^{*} P<0.05$ vs. control group; $\# P<0.05$ vs. $\mathrm{H}_{2} \mathrm{O}_{2}$ group

\section{Effects of miR143 on HK2 and ADRB1 expression}

To further explore the role of miR143 predicted downstream target proteins $\mathrm{HK} 2$ and ADRB1 in MSC-CM amelioration of $\mathrm{H}_{2} \mathrm{O}_{2}$ injury ( $1 \mathrm{mM} \mathrm{H}_{2} \mathrm{O}_{2}$ for $3 \mathrm{~h}$ ), western blot analysis was applied. The expression of HK2 and ADRB1 was significantly decreased in the $\mathrm{H}_{2} \mathrm{O}_{2}$ group compared to that of the control group, whereas it was significantly increased in the $\mathrm{H}_{2} \mathrm{O}_{2}+$ MSC-CM group (Fig. $6 \mathrm{a}-\mathrm{b}, \mathrm{P}<0.05$ ). Furthermore, the levels of HK2 and ADRB1 decreased in the miR143 mimics group, but increased in the inhibitor group for the L02 cells under normal incubation (Fig. 6d and f, $P<0.05$ ) and the cells incubated with $0.8 \mathrm{mM} \mathrm{H}_{2} \mathrm{O}_{2}$ for $2 \mathrm{~h}$ after miRNA transfection for $60 \mathrm{~h}$ (Fig. $6 \mathrm{e}$ and $\mathrm{g}, P<0.05$ ). It is worth mentioning that the difference in HK2 and ADRB1 expression levels between the miR143 mimics group and the inhibitor group markedly increased under $\mathrm{H}_{2} \mathrm{O}_{2}$ injury.

\section{Effects of miR143 on L02 apoptosis after transfection for $60 \mathrm{~h}$}

According to the flow cytometric analysis with AnnexinV/ PI staining, the percentage of apoptotic cells was higher in the miR143 mimics group compared to the inhibitor group $(28.59 \% \pm 2.36 \%$ vs. $15.13 \% \pm 1.27 \%$, Fig. $7 \mathrm{a}-\mathrm{b}, P<0.05)$. Alternatively, JC-1 staining showed the percent of cells with mitochondrial membrane potential depolarization was $3.85 \% \pm 0.15 \%$ in the miR143 inhibitor group, while it was $36.78 \% \pm 1.15 \%$ in the miR 143 mimics group (Fig. $7 c-d, P<0.05$ ). In the case of $\mathrm{H}_{2} \mathrm{O}_{2}$ induced injury, the percentage of apoptotic cells reached
$54.98 \% \pm 5.05 \%$ and $75.47 \% \pm 9.43 \%$ in the miR 143 inhibitor and miR143 mimics groups, respectively. The apoptosis rate of the inhibitor $\mathrm{NC}+\mathrm{H}_{2} \mathrm{O}_{2}$ group was $63.09 \% \pm 10.87 \%$ and for the $\mathrm{NC}+\mathrm{H}_{2} \mathrm{O}_{2}$ group it was $62.74 \% \pm 9.47 \%$ (Fig. $8 \mathrm{a}-\mathrm{b}, \mathrm{P}<0.05$ ).

Apoptosis-related proteins were utilized to reflect cellular apoptosis. In order to further investigate the function of miR143, expression levels of Bcl-2 and Bax were detected in the miR143-transfected group with $\mathrm{H}_{2} \mathrm{O}_{2}$ injury (0.8 $\mathrm{mM} \mathrm{H}_{2} \mathrm{O}_{2}$ for $2 \mathrm{~h}$ ). Bax expression was significantly increased in the miR143 mimics $+\mathrm{H}_{2} \mathrm{O}_{2}$ group, and was low in the control group and $\mathrm{NC}+$ $\mathrm{H}_{2} \mathrm{O}_{2}$ group. However, Bax expression was significantly lower in the inhibitor $+\mathrm{H}_{2} \mathrm{O}_{2}$ group compared to that in the inhibitor $\mathrm{NC}+\mathrm{H}_{2} \mathrm{O}_{2}$ and control groups. On the other hand, Bcl-2 expression was significantly decreased in the miR143 mimics $+\mathrm{H}_{2} \mathrm{O}_{2}$ group compared to that in the $\mathrm{NC}+\mathrm{H}_{2} \mathrm{O}_{2}$ and $\mathrm{H}_{2} \mathrm{O}_{2}$ groups, whereas it was significantly higher in the inhibitor $+\mathrm{H}_{2} \mathrm{O}_{2}$ group compared to that in the inhibitor $\mathrm{NC}+\mathrm{H}_{2} \mathrm{O}_{2}$ and $\mathrm{H}_{2} \mathrm{O}_{2}$ groups. In the $\mathrm{H}_{2} \mathrm{O}_{2}$ injury group, $\mathrm{Bcl}-2$ expression decreased, while Bax expression increased in both the upregulation and down-regulation of miR143. However, a much greater decrease of Bcl-2 expression levels and increase of Bax levels were observed with the up-regulation of miR143, compared with miR143 down-regulation. Furthermore, the $\mathrm{Bcl}-2 / \mathrm{Bax}$ ratio was significantly reduced in the miR143 mimics group compared to the inhibitor group (Fig. 9a-b, $P<0.05$ ). These changes in Bax and Bcl2 were consistent with $\mathrm{H}_{2} \mathrm{O}_{2}$ decreased the $\mathrm{Bcl}-2 / \mathrm{Bax}$ ratio significantly in comparison with the control, while 


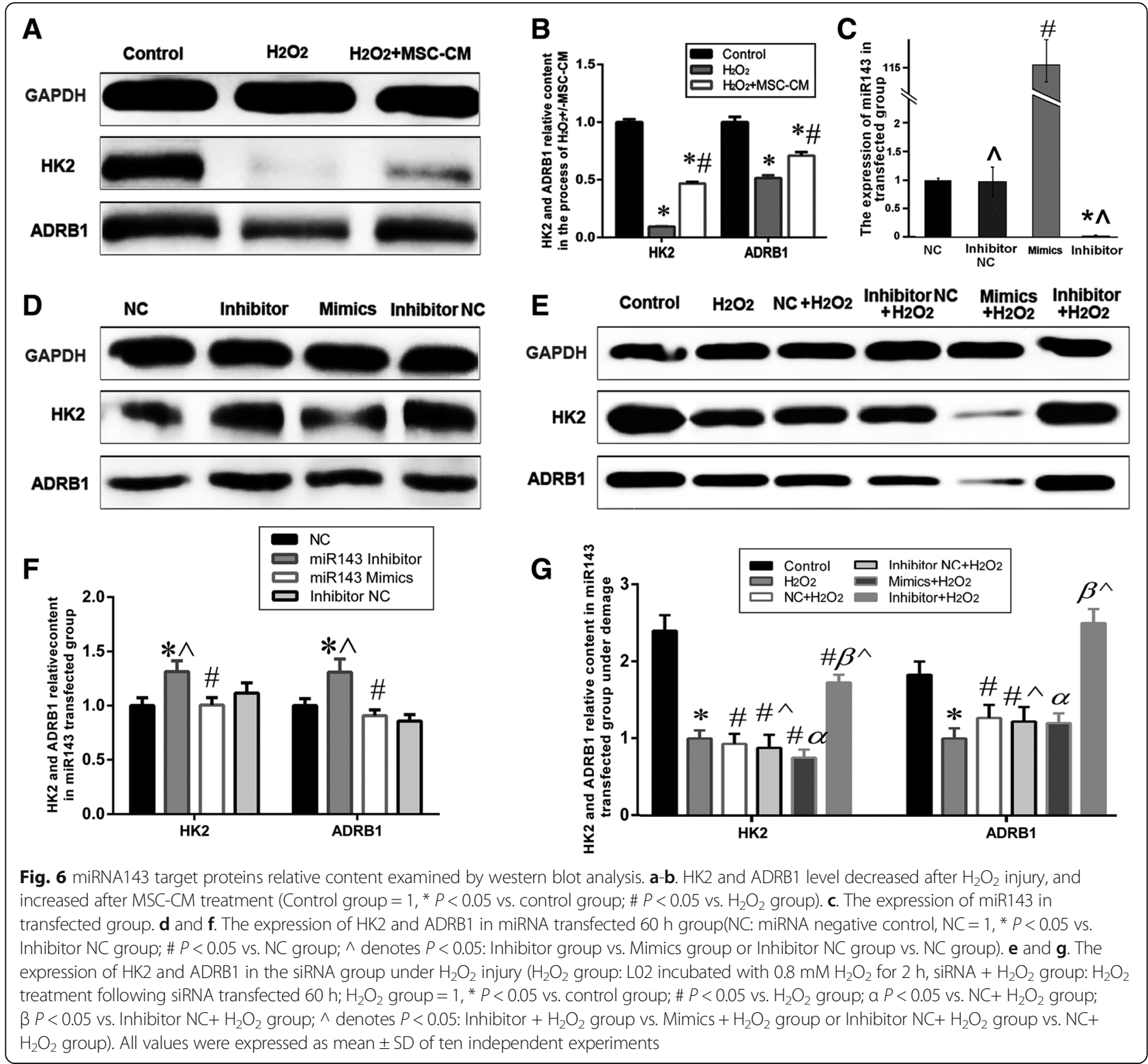

MSC-CM remarkably restored this ratio under the condition of $\mathrm{H}_{2} \mathrm{O}_{2}$ injury and MSC-CM treatment. These results indicated that miR143 was associated with apoptosis.

Effects of miR143 on L02 cells proliferation and cell cycle According to the CCK -8 analysis, $11.21 \% \pm 3.76 \%$ of the L02 cells were viable in the miR143 inhibitor group as compared to the mimics group at $60 \mathrm{~h}$ after transfection (Fig. 10a, $P<0.05$ ). In addition, the viability of L02 cells increased by $14.5 \% \pm 3.17 \%$ and $18.9 \% \pm 3.94 \%$ at 48 and $60 \mathrm{~h}$ respectively in the miR143 inhibitor group as compared to the mimics group, when subjected to $\mathrm{H}_{2} \mathrm{O}_{2}$ injury $\left(0.8 \mathrm{mM} \mathrm{H}_{2} \mathrm{O}_{2}\right.$ for $\left.2 \mathrm{~h}\right)$ following transfection (Fig. 10b, $P<0.05$ ).
Meanwhile, over-expression of miR143 also resulted in a marked increase in the percentage of the cell population in the G0/G1 phase and a sharp decrease in the $\mathrm{S}+$ G2/M phase as compared to the down-regulation of miR143 after transfection for $60 \mathrm{~h}$ (Fig. 10c-d, $P<0.05$ ). After $\mathrm{H}_{2} \mathrm{O}_{2}$ injury, a significant increase in the percentage of the cell population in G0/G1 phase was observed in the miR143 mimics group, when compared with the miR143 inhibitor. Furthermore, the percentage of cells in the $\mathrm{S}+\mathrm{G} 2 / \mathrm{M}$ phase in the miR143 mimics group was significantly lower than that in the inhibitor group under oxidative stress injury (Fig. 10e-f, $P<0.05$ ). On the other hand, the rates of occurrence of G0/G1 and S + $\mathrm{G} 2 / \mathrm{M}$ stages were significantly different between the miR143 inhibitor and mimics groups under $\mathrm{H}_{2} \mathrm{O}_{2}$ 


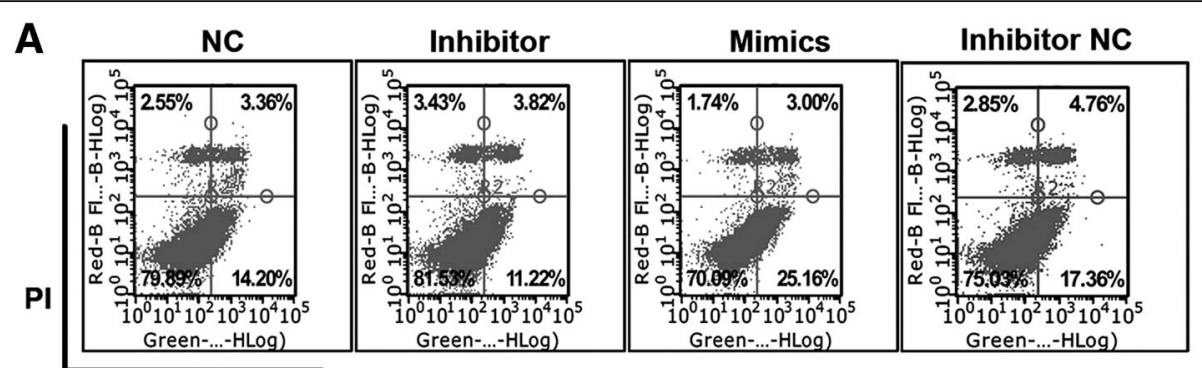

Annexin V

B

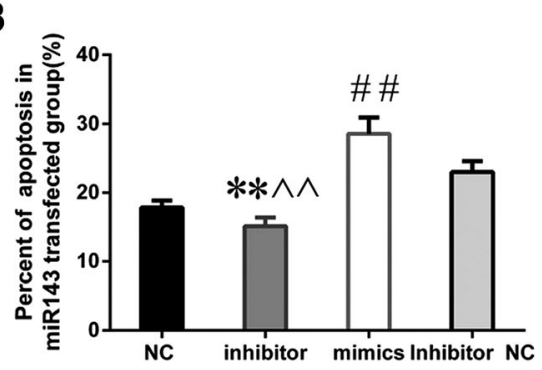

C

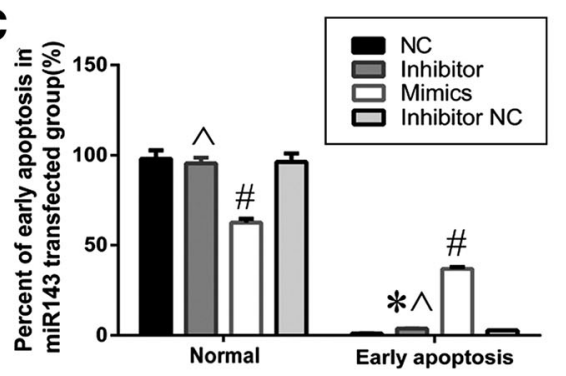

Inhibitor

\section{Mimics Inhibitor NC}

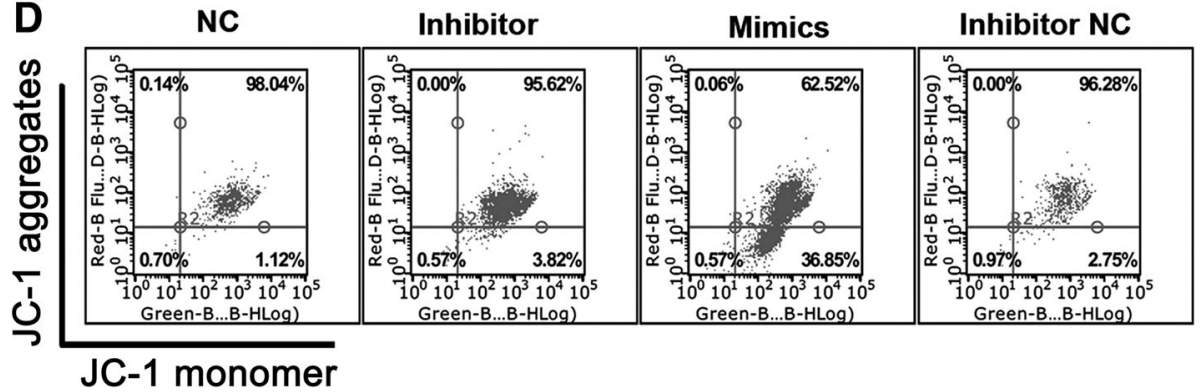

Fig. 7 miR143 promotes L02 apoptosis after transfection for 60 h. a-b. miR143 accelerated L02 apoptosis examined by Annexin V/PI double staining and flow cytometry. c-d. miR143 aggravated L02 MMP depolarization examined by JC-1 staining and flow cytometry. The lower right quadrant: MMP depolarization. ( $n=10,{ }^{*} P<0.05$ and ${ }^{* *} P<0.01$ vs. Inhibitor NC group; $\# P<0.05$ and \#\#P<0.01 vs. NC group; $\wedge P<0.05$ and $\wedge \wedge P<0.01$ vs. Mimics group)

injury (Fig. 10d-e, $P<0.05$ ). The results indicated that miR143 induces cell cycle arrest, which is in accordance with the alteration of cell cycle in $\mathrm{H}_{2} \mathrm{O}_{2}$ injury and MSC-CM treatment.

\section{Discussion}

A growing knowledge of the relation between aberrant miRNA expression and hepatocyte injury [22, 23]. Studies suggest that MSC-CM possesses the capacity to change the expression of miRNA, leading to alteration in the cell microenvironment, and play a prominent role in cell repair [17]. In this study, the therapeutic potential of MSC-CM to alleviate $\mathrm{H}_{2} \mathrm{O}_{2}$ injury in hepatocytes was further examined along with the possible underlying mechanisms of this function. Our study demonstrates that MSC-CM protects hepatic L02 cells from injury by adjusting apoptosis, mitosis, proliferation, and the expression of miRNA. Current evidence indicates that miRNAs play an important role in the heart $[24,25]$, kidney [26], and brain [27, 28] hypoxia impairment and
MSC-CM repair. RT-PCR was applied to screen differentially expressed miRNA, and miR143 was selected. The predicted target proteins of miR143 were detected by bioinformatics algorithms, and then verified by western blot. Over-expression or down-regulation of miR143 aggravated or alleviated hepatocyte apoptosis induced by $\mathrm{H}_{2} \mathrm{O}_{2}$, respectively. In addition to increased apoptosis, reduced cell proliferation and cell cycle progression were observed in L02 cells over-expressing miR143 after $\mathrm{H}_{2} \mathrm{O}_{2}$ injury. Furthermore, decreased expression of predicted miR143 target proteins, HK2 and ADRB1, and reduced $\mathrm{Bcl}-2 / \mathrm{Bax}$ ratio were observed upon miR143 over-expression. We postulate that miR143 inhibits Bcl-2 expression and activates Bax and caspase- 9 and thereby the endogenous mitochondrial pathway, which promotes cell apoptosis. Zhang's research indicated that Bcl-2 might be a target gene of miR143 [29]. In addition, miR143 may target HK2 [30] and ADRB1 and play an important role in proliferation and apoptosis during $\mathrm{H}_{2} \mathrm{O}_{2}$ induced injury. 

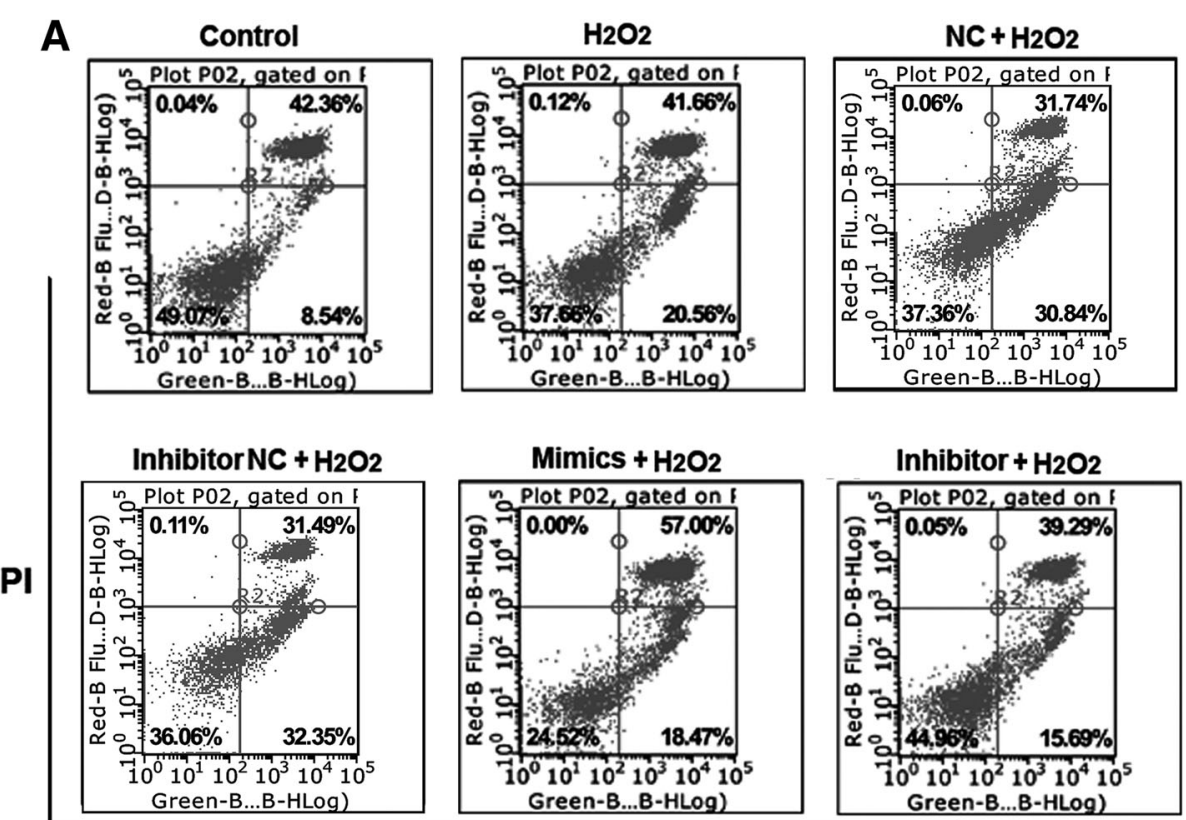

B

\section{Annexin V}

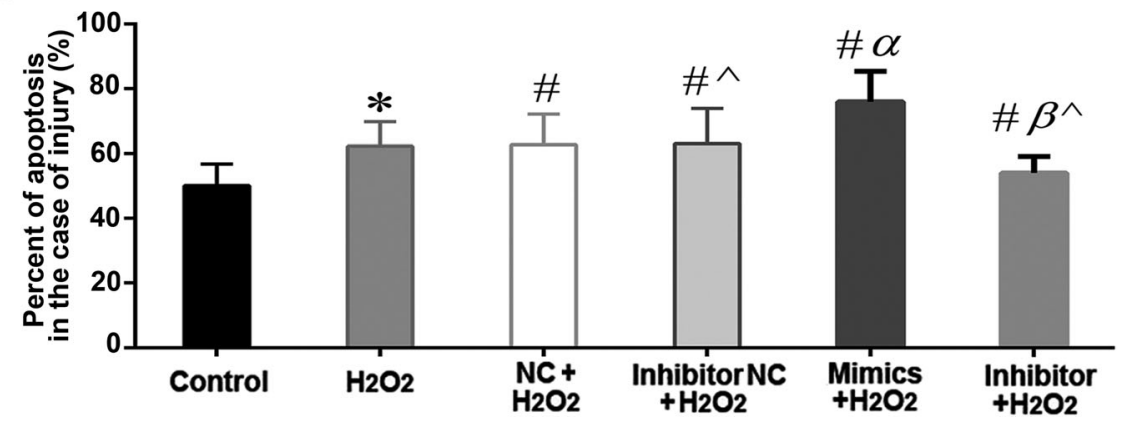

Fig. 8 miR143 promotes $L 02$ apoptosis in the case of $\mathrm{H}_{2} \mathrm{O}_{2}$ injury. a-b. miR143 overexpression accelerated L02 apoptosis, down regulated miR143 protected L02 cells from apoptosis (The lower left quadrant represents normal cells). $n=10,{ }^{*} P<0.05$ vs. control group; $\# P<0.05$ vs. $\mathrm{H}_{2} \mathrm{O}_{2}$ group; a $P<0.05$ vs. $\mathrm{NC}+\mathrm{H}_{2} \mathrm{O}_{2}$ group; $\beta P<0.05$ vs. Inhibitor $\mathrm{NC}+\mathrm{H}_{2} \mathrm{O}_{2}$ group; $\wedge$ denotes $P<0.05$ : Inhibitor $+\mathrm{H}_{2} \mathrm{O}_{2}$ group vs. Mimics $+\mathrm{H}_{2} \mathrm{O}_{2}$ group or Inhibitor $\mathrm{NC}+\mathrm{H}_{2} \mathrm{O}_{2}$ group vs. $\mathrm{NC}+\mathrm{H}_{2} \mathrm{O}_{2}$ group

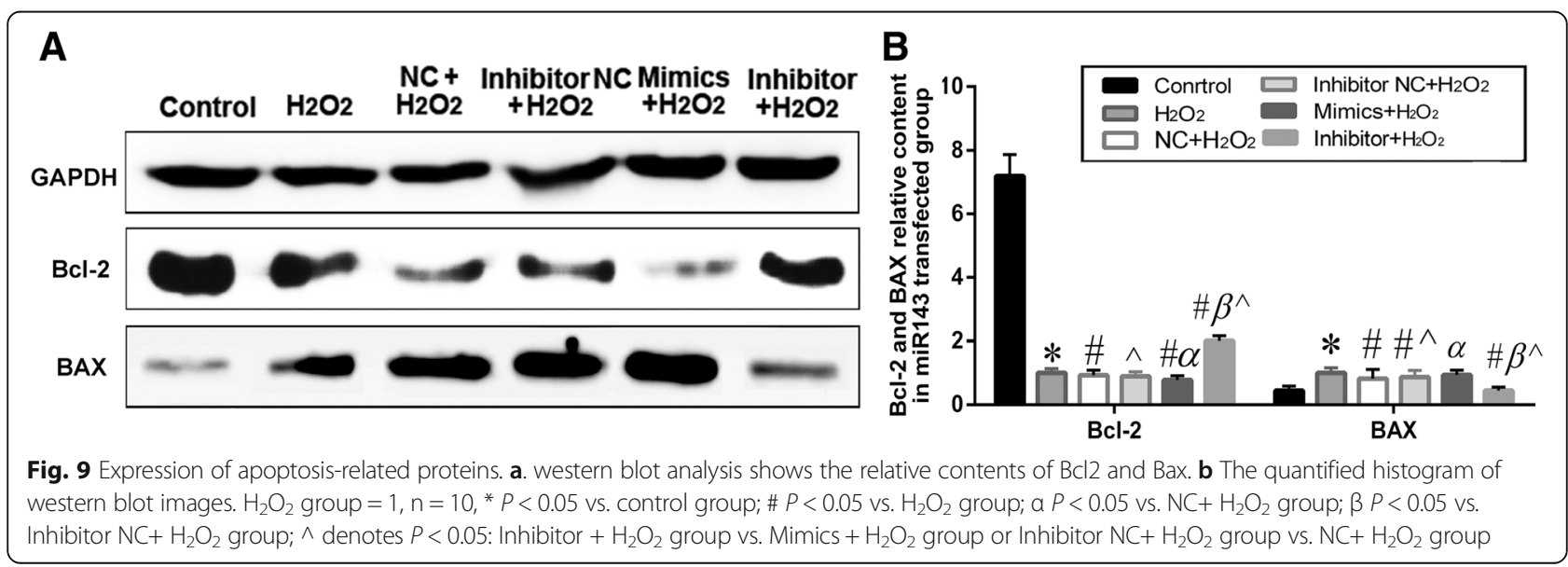




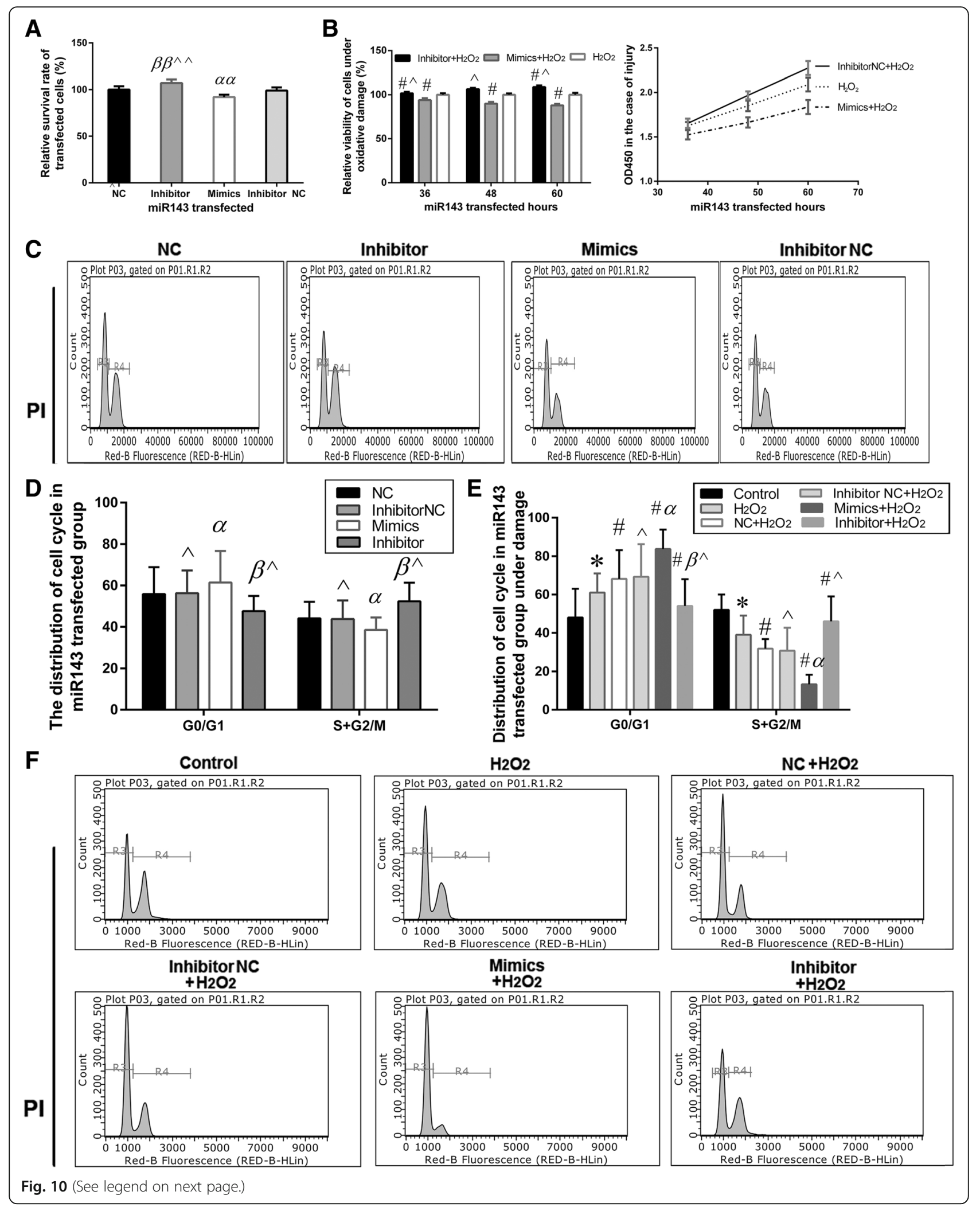


(See figure on previous page.)

Fig. 10 Effects of miR143 on L02 cell proliferation and cell cycle. a Effects of miR143 on cell proliferation and analysis ( $N C$ group $=1$, aa $P<0.01$ vs. NC group; $\beta \beta P<0.01$ vs. Inhibitor NC group; $\wedge \wedge P<0.01$ vs. Mimics group). b. Effects of miR143 on cell proliferation and analysis under $\mathrm{H}_{2} \mathrm{O}_{2}$ injury $\left(\mathrm{H}_{2} \mathrm{O}_{2}\right.$ group $=1$, \# $P<0.05$ vs. $\mathrm{H}_{2} \mathrm{O}_{2}$ group; $\wedge P<0.05$ vs Mimics $+\mathrm{H}_{2} \mathrm{O}_{2}$ group). c-d. Cell cycle distribution in L02 cells and analysis. e-f. Cell cycle distribution and analysis under $\mathrm{H}_{2} \mathrm{O}_{2}$ injury ${ }^{*} P<0.05$ vs. control group; $\#<0.05$ vs. $\mathrm{H}_{2} \mathrm{O}_{2}$ group; a $P<0.05$ vs. $\mathrm{NC}+\mathrm{H}_{2} \mathrm{O}_{2}$ group; $\beta P<0.05$ vs. Inhibitor $\mathrm{NC}+\mathrm{H}_{2} \mathrm{O}_{2}$ group; $\wedge$ denotes $P<0.05$ : Inhibitor $+\mathrm{H}_{2} \mathrm{O}_{2}$ group vs. Mimics $+\mathrm{H}_{2} \mathrm{O}_{2}$ group or Inhibitor $\mathrm{NC}+\mathrm{H}_{2} \mathrm{O}_{2}$ group vs. $\mathrm{NC}+\mathrm{H}_{2} \mathrm{O}_{2}$ group). All values were expressed as mean $\pm \mathrm{SD}$ of ten independent experiments

However, it has been identified that miR143 suppresses tumor cell growth and migration, silencing the KRAS (V-Ki-ras2 Kirsten rat sarcoma viral oncogene homolog) gene, and adjusting glucose metabolism via the miR143/ HK2 axis [30, 31]. Notably, recent studies found that miR143 is an essential regulator of cancer glycolysis via targeting HK2 in lung [32], liver [33], and breast [34] cancer, and glioblastoma multiform cells [35]. However, the function of miR143 in glycolysis in liver cells during hypoxia has not been fully understood. In this study, we found that both $\mathrm{H}_{2} \mathrm{O}_{2}$ injury and up-regulation of miR143 can increase the expression level of miR143 but decrease the levels of HK2 and ADRB1. These results provide new evidence that hypoxia participates in the regulation of miR143 expression, indicating that reduction of HK2 and ADRB1 expression is responsible for the change of miR143 under $\mathrm{H}_{2} \mathrm{O}_{2}$ injury. Prominently, we speculated that miR143 exerts its glycometabolism function in hepatocyte injury by specifically targeting HK2. In addition, several studies have indicated that binding HK2 to the mitochondrial membrane accelerates the Warburg effect, which is characterized by adjusting glucose metabolism [36, 37]. Hexokinase (HK) 2 is a pivotal enzyme in glucose metabolism and catalyzes the irreversible rate-limiting step in the glycolytic pathway [38]. Recent studies have demonstrated that over-expression of HK2 has been observed in human liver cancer and it is associated with poor overall survival in patients [33]. The results of the present study demonstrated that miR143 is often up regulated and expression of HK2 is down regulated in L02 cells under $\mathrm{H}_{2} \mathrm{O}_{2}$ injury. These results indicate that miR143 may directly target the 3'-UTR of HK2, thereby suppressing glucose consumption, lactate production, cellular G6P and ATP levels, and cell proliferation of liver cells under $\mathrm{H}_{2} \mathrm{O}_{2}$ injury. MSC-CM contains large numbers of cytokines, promoting cell growth after $\mathrm{H}_{2} \mathrm{O}_{2}$ is removed [14-16], and MSC-CM can provide a biosynthetic advantage for cell proliferation. It is reasonable to suggest that MSC-CM may have the potential to affect $\mathrm{L} 02$ cells subjected to $\mathrm{H}_{2} \mathrm{O}_{2}$ injury by reparation through adjusting glycolysis. In short, the mechanism of promoting hepatic L02 cell proliferation by regulating the miR143/HK2 axis in the MSC-CM protected group is consistent with previous studies.

Several $\beta$ adrenoceptor antagonists have been shown to provide brain protection in in-vivo studies, Goyagi et al. have been confirmed [39], while, stimulation of $\beta$-adrenergic receptors increases cardiac myocyte apoptosis in vivo and in vitro [40-43]. Recent research shows that augmented hepatic $\beta$-AR signaling during aging may increase lipid accumulation in the liver $[44,45]$. Hence, the major findings of our study are that $\mathrm{H}_{2} \mathrm{O}_{2}$ injury and miR143 over-expression decreased ADRB1 expression, but this was restored following MSC-CM treatment and miR143 down-regulation. We speculate that miR143 alleviates $\mathrm{H}_{2} \mathrm{O}_{2}$-induced apoptosis through specifically activating ADRB1 under hypoxia. Some research showed that during ischemia, PKA activation causes inactivation of cytochrome- $c$ oxidase and contributes to myocardial damage due to ischemia-reperfusion. It is speculated that $\beta$-adrenergic stimulation during ischemia activates $P K A$ via endogenous catecholamine release [46]. Hence $\beta$-adrenergic stimulation may mediate both myocardial protection and damage during ischemia. ADRB1 plays a critical protective role in hypoxia/reoxygenation-induced neonatal rat cardiomyocyte injury in vitro [47]. Swift et al. indicated that ADRB1 agonist treatment during dobutamine disuse mitigates negative changes in cancellous bone microarchitecture and inhibits increases in osteocyte apoptosis [48]. In addition, Zapater et al. proposed that Beta-adrenergic receptor-1 antagonist accelerates liver norepinephrine modulation of the pro-inflammatory response in $\mathrm{CCl}(4)$-treated mice [49]. ADRB1 expression was restored after MSC-CM treatment. It is possible that the ADRB1 protection mechanism also contributes to the reparation of L02 cells. According to the results, we speculated that miR143 attenuates $\mathrm{H}_{2} \mathrm{O}_{2}$-induced hepatocyte injury following MSC-CM treatment through specifically activating ADRB1.

\section{Conclusions}

In summary, this study showed that MSC-CM has dramatic potential to alleviate $\mathrm{H}_{2} \mathrm{O}_{2}$ induced oxidative stress injury and demonstrated for the first time that miRNA is involved in the molecular mechanism of the therapeutic effect of MSC-CM on hepatocyte injury. Interestingly, miR143, via adjusting downstream target proteins, was also involved in the molecular mechanism underlying the therapeutic effect of MSC-CM on oxidative stress injury by adjusting the expression of HK2 and ADRB1. Future study endeavors will be required to probe into the precise regulatory mechanisms of how miRNAs exert their functions and elucidate the signaling pathways targeted by miRNAs in MSC-CM protected hepatocytes during $\mathrm{H}_{2} \mathrm{O}_{2}$ induced apoptosis and necrosis. 


\section{Additional file}

Additional file 1: The 19 miRNAs with significant differences in expression in cirrhotic rats treated with MSC. $P<0.05$. (DOCX $12 \mathrm{~kb}$ )

\section{Abbreviations}

ADRB1: Beta-1 adrenergic receptor; BMF: Modifying factor; FBS: Fetal bovine serum; GAPDH: Glyceraldehyde 3-phosphate dehydrogenase; $\mathrm{H}_{2} \mathrm{O}_{2}$ : Hydrogen peroxide; HK2: Hexokinase II; HRP: Horseradish peroxidase; miRNA: microRNA; MSC: Mesenchymal stem cell; MSC-CM: Mesenchymal stem cell-conditioned medium; OD: Optical density; PCR: Polymerase chain reaction; PI: Propidium iodide; RT: Reverse transcriptase

\section{Acknowledgments}

We are grateful to Panpan Zhou and Jing Lan for their kind help in Culture of human umbilical-cord-derived MSCs.

\section{Funding}

This work was supported by Shenzhen science and technology research and Development Fund (JCYJ20140418115449178), Shandong Province Major scientific research projects (2017GSF18155), Innovation Fund Project of Shandong University (2014QLKY02), and Ji'nan science and technology development Foundation (201403010)

\section{Availability of data and materials}

The datasets generated and analysed during the current study are available from the corresponding author on reasonable request.

\section{Authors' contributions}

XJX participated in the study design, performed laboratory work and statistical analysis, prepared the drafts of the manuscript and revised it according to advice from the other authors. DL participated in the study design, assisted in statistical analysis and drafting the manuscript, revised the manuscript. XL and QS assisted in acquisition of data, analysis and interpretation of data, statistical analysism, revised manuscript. XLJ and DL were responsible for the study design and revised the manuscript for important intellectual content. All the authors have given final approval of the version to be published and agree to be accountable for all aspects of this work.

\section{Authors' information}

$\mathrm{XLJ}$ is a professor in the Department of Pediatrics, and director of cryomedicine laboratory, Qilu Hospital, Shandong University, China. Her present research areas include specific genetic screening of childhood leukemia and stem cells clinical applications. She ever completed Major State Basic Research Development Program as a main participant. She is currently in charge of over three projects funded by Shandong Province Natural Science Foundation and Shenzhen science and technology research and Development Fund. Besides several invention patents being granted, she has authored over 30 scientific publications.

$\mathrm{DL}$ is a professor in the Department of Pediatrics, and vice director of cryomedicine laboratory, Qilu Hospital, Shandong University, China. His present research areas include specific genetic screening of childhood leukemia, stem cells clinical applications, research of gastrointestinal microorganisms and micro environment and the study of miRNA regulatory mechanism. He ever completed 973 Project as a main participant. He is currently in charge of over several projects funded by Shandong Province Natural Science Foundation. Besides several invention patents are granted, he has authored over 100 scientific publications.

\section{Ethics approval and consent to participate}

Ethical approval for this study involving human umbilical cord samples from obstetrics department of Qilu hospital healthy donors was granted by the institutional review board of the Shandong University Qilu Hospital (approval number: 2012-021). Written informed consent was obtained from all the patients according to the Declaration of Shandong University Qilu Hospital. All experimental protocols involving animals were reviewed and approved by the Institutional Animal Care and Use Committee of Shandong University Qilu Hospital (approval number: 2012-036)

\section{Consent for publication}

Not applicable.

\section{Competing interests}

The authors declare that they have no competing interests.

\section{Publisher's Note}

Springer Nature remains neutral with regard to jurisdictional claims in published maps and institutional affiliations.

Received: 18 February 2017 Accepted: 6 December 2017 Published online: 19 December 2017

\section{References}

1. Mirtschink P, Krishnan J, Grimm F, Fankhauser N, Christinat Y, Cortijo C, Feehan O, Vukolic A, Sossalla S, Stehr SN, Ule J, Zamboni N, Pedrazzini T, Krek W. HIF-driven SF3B1 induces KHK-C to enforce fructolysis and heart disease. Nature. 2015;522(7557):444-9.

2. Kimura W, Xiao F, Canseco DC, Muralidhar S, Thet S, Shelton JM, Richardson JA, Ashour AM, Asaithamby A, Liang H, Xing C, Lu Z, Zhang CC, Sadek HA. Hypoxia fate mapping identifies cycling cardiomyocytes in the adult heart. Nature. 2015:523(7559):226-30.

3. Duran J, Guinovart JJ. Brain glycogen in health and disease. Mol Asp Med 2015:46:70-7.

4. Cheng SC, Quintin J, Cramer RA, Shepardson KM, Saeed S, Kumar V, Giamarellos-Bourboulis EJ, Martens JH, Rao NA, Aghajanirefah A, Manjeri GR, Li Y, Ifrim DC, Arts RJ. mTOR- and HIF-1a-mediated aerobic glycolysis as metabolic basis for trained immunity. Science. 2014:345(6204):1250684.

5. Eltzschig HK, Eckle T. Ischemia and reperfusion-from mechanism to translation. Nat Med. 2011;17(11):1391-401.

6. Andreev DE, O'Connor PB, Zhdanov AV, Dmitriev RI, Shatsky IN, Papkovsky DB, Baranov PV. Oxygen and glucose deprivation induces widespread alterations in mRNA translation within 20 minutes. Genome Biol. 2015:16:90.

7. Rowart $P$, Erpicum $P$, Detry $O$, Weekers L, Grégoire C, Lechanteur C, Briquet A, Beguin Y, Krzesinski JM, Jouret F. Mesenchymal Stromal cell therapy in ischemia/reperfusion injury. J Immunol Res. 2015;2015:602597.

8. Khubutiya MS, Vagabov AV, Temnov AA, Sklifas AN. Paracrine mechanisms of proliferative, anti-apoptotic and anti-inflammatory effects of mesenchymal stromal cells in models of acute organ injury. Cytotherapy. 2014:16(5):579-85

9. Haga H, Yan IK, Takahashi K, Matsuda A, Patel T. Extracellular vesicles from bone marrow-derived Mesenchymal stem cells improve survival from lethal hepatic failure in mice. Stem Cells Transl Med. 2017;6(4):1262-72.

10. Lotfinia M, Kadivar M, Piryaei A, Pournasr B, Sardari S, Sodeifi N. Effect of secreted molecules of human embryonic stem cell-derived Mesenchymal stem cells on acute hepatic failure model. Stem Cells Dev. 2016;25(24): 1898-08.

11. Chen $Y X$, Zeng ZC, Sun J, Zeng HY, Huang $Y$, Zhang ZY. Mesenchymal stem cell-conditioned medium prevents radiation-inducedliver injury by inhibiting inflammation and protecting sinusoidal endothelial cells. J Radiat Res. 2015;56(4):700-8.

12. Zhang Y, Xia X, Yan J, Yan L, Lu C, Zhu X. Mesenchymal stem cell-derived angiogenin promotes primodial follicle survival and angiogenesis in transplanted human ovarian tissue. Reprod Biol Endocrinol. 2017;15(1):18.

13. Fu X, He Y, Xie C, Liu W. Bone marrow mesenchymal stem cell transplantation improves ovarianfunction and structure in rats with chemotherapy-induced ovarian damage. Cytotherapy. 2008;10(4):353-63.

14. Liang X, Ding Y, Zhang Y, Tse HF, Lian Q. Paracrine mechanisms of mesenchymal stem cell-based therapy: current status and perspectives. Cell Transplant. 2014;23(9):1045-59

15. Weil BR, Markel TA, Herrmann JL, Abarbanell AM, Meldrum DR Mesenchymal stem cells enhance the viability and proliferation of human fetal intestinal epithelial cells following hypoxic injury via paracrine mechanisms. Surgery. 2009;46(2):190-7.

16. Spees JL, Lee RH, Gregory CA. Mechanisms of mesenchymal stem/stromal cell function. Stem Cell Res Ther. 2016;7(1):125.

17. Clark EA, Kalomoiris S, Nolta JA, Fierro FA. Concise review: MicroRNA function in multipotent mesenchymal stromal cells. Stem Cells. 2014;32(5): 1074-82.

18. Ebert MS, Sharp PA. Roles for microRNAs in conferring robustness to biological processes. Cell. 2012;149(3):515-24. 
19. Fu J, Zhang $H$, Zhuang Y, Liu H, Shi Q, Li D, Ju X. The role of Nacetyltransferase 8 in mesenchymal stem cell-based therapy for liver ischemia/reperfusion injury in rats. PLoS One. 2014;9(7):e103355.2.

20. Perez-Galarza J, Carlotti F, Rabelink MJ, Cramer S, Hoeben RC, Fibbe WE, van Pel M. Optimizing reporter constructs for in vivo bioluminescence imaging of IFN-y stimulated mesenchymal stromal cells. Exp Hematol. 2014;42:793-803.

21. Lu Y, Xu S, Chen H, He M, Deng Y, Cao Z, Pi H, Chen C, Li M, Ma Q, Gao P, Ji Y, Zhang L, Yu Z, Zhou Z. CdSe/ZnS quantum dots induce hepatocyte pyroptosis and liver inflammation pyroptosis and liver inflammation via NLRP3 inflammasomeactivation. Biomaterials. 2016:90:27-39.

22. Gottlieb RA, Pourpirali S. Lost in translation: miRNAs and mRNAs in ischemic preconditioning and ischemia/reperfusion injury. J Mol Cell Cardiol. 2016:95:70-7.

23. Nallamshetty S, Chan SY, Loscalzo J. Hypoxia: a master regulator of microRNA biogenesis and activity. Free Radic Biol Med. 2013;64:20-30.

24. Wen Z, Zheng S, Zhou C, Yuan W, Wang J, Wang T. Bone marrow mesenchymal stem cells for post-myocardial infarction cardiac repair: microRNAs as novel regulators. J Cell Mol Med. 2012;16(4):657-71.

25. Wen Z, Huang W, Feng Y, Cai W, Wang Y, Wang X, Liang J, Wani M, Chen J, Zhu P, Chen JM, Millard RW, Fan GC, Wang Y. MicroRNA-377 regulates mesenchymal stem cell-induced angiogenesis in ischemic hearts by targeting VEGF. PLoS One. 2014;9(9):e104666.

26. Cantaluppi V, Gatti S, Medica D, Figliolini F, Bruno S, Deregibus MC, Sordi A, Biancone L, Tetta C, Camussi G. Microvesicles derived from endothelial progenitor cells protect the kidney from ischemia-reperfusion injury by microRNA-dependent reprogramming of resident renal cells. Kidney Int. 2012;82(4):412-27.

27. Xin H, Li Y, Chopp M. Exosomes/miRNAs as mediating cell-based therapy of stroke. Front Cell Neurosci. 2014;8:377.

28. Ophelders DR, Wolfs TG, Jellema RK, Zwanenburg A, Andriessen P, Delhaas T, Ludwig AK, Radtke S, Peters V, Janssen L, Giebel B, Kramer BW. Mesenchymal Stromal cell-derived extracellular vesicles protect the Fetal brain after hypoxia-ischemia. Stem Cells Transl Med. 2016;5(6):754-63.

29. Zhang H, Cai $X$, Wang $Y$, Tang H, Tong D, Ji F. microRNA-143, downregulated in osteosarcoma, promotes apoptosis and suppresses tumorigenicity by targeting BCl-2. Oncol Rep. 2010;24(5):1363-9.

30. Zhou P, Chen WG, Li XW. MicroRNA-143 acts as a tumor suppressor by targeting hexokinase 2 in human prostate cancer. Am J Cancer Res. 2015; 5(6):2056-63.

31. Xu B, Niu X, Zhang X, Tao J, Wu D, Wang Z, Li P, Zhang W, Wu H, Feng N, Wang Z, Hua L, Wang X. miR-143 decreases prostate cancer cells proliferation and migration and enhances their sensitivity to docetaxel through suppression of KRAS. Mol Cell Biochem. 2011;350(1-2):207-13.

32. Fang $R$, Xiao T, Fang Z, Sun Y, Li F, Gao Y, Feng Y, Li L, Wang Y, Liu X, Chen H, Liu XY, Ji H. MicroRNA-143 (miR-143) regulates cancer glycolysis via targeting hexokinase 2 gene. J Biol Chem. 2012;287(27):23227-35.

33. Kwee SA, Hernandez B, Chan O, Wong L. Choline kinase alpha and hexokinase-2 protein expression in hepatocellular carcinoma: association with survival. PLoS One. 2012;7(10):e46591.

34. Jiang S, Zhang LF, Zhang HW, Hu S, Lu MH, Liang S, Li B, Li Y, Li D, Wang ED, Liu MF. A novel miR-155/miR-143 cascade controls glycolysis by regulating hexokinase 2 in breast cancer cells. EMBO J. 2012;31(8):1985-98.

35. Wolf A, Agnihotri S, Micallef J, Mukherjee J, Sabha N, Cairns R, Hawkins C, Guha A. Hexokinase 2 is a key mediator of aerobic glycolysis and promotes tumor growth in human glioblastoma multiforme. J Exp Med. 2011;208(2): 313-26.

36. Mathupala SP, Ko YH, Pedersen PL. Hexokinase-2 bound to mitochondria: cancer's stygian link to the "Warburg effect" and a pivotal target for effective therapy. Semin Cancer Biol. 2009;19(1):17-24.

37. Vander Heiden MG, Cantley LC, Thompson CB. Understanding the Warburg effect: the metabolic requirements of cell proliferation. Science. 2009; 324(5930):1029-33.

38. Mathupala SP, Rempel A, Pedersen PL. Aberrant glycolytic metabolism of cancer cells: a remarkable coordination of genetic, transcriptional, posttranslational, and mutational events that lead to a critical role for type ॥ hexokinase. J Bioenerg Biomembr. 1997;29(4):339-43.

39. Goyagi T, Horiguchi T, Nishikawa T, Tobe Y. Post-treatment with selective $\beta 1$ adrenoceptor antagonists provides neuroprotection against transient focal ischemia in rats. Brain Res. 2010;1343:213-7.

40. Singh K, Xiao L, Remondino A, Sawyer DB, Colucci WS. Adrenergic regulation of cardiac myocyte apoptosis. J Cell Physiol. 2001;189(3):257-65.
41. Remondino A, Kwon SH, Communal C, Pimentel DR, Sawyer DB, Singh K, Colucci WS. $\beta$-adrenergic receptor-stimulated apoptosis in cardiac myocytes is mediated by reactive oxygen species/c-Jun NH2-terminal kinase-dependent activation of the mitochondrial pathway. Circ Res. 2003;92(2):136-8.

42. Wang Y, Wang Y, Yang D, Yu X, Li H, Lv X, Lu D, Wang H. B1-adrenoceptor stimulation promotes LPS-induced cardiomyocyte apoptosis through activating PKA and enhancing CaMKII and IKBa phosphorylation. Crit Care. 2015;19:76.

43. Seqqat R, Guo X, Rafiq K, Kolpakov MA, Guo J, Koch WJ, Houser SR, Dell'italia $\sqcup$. Beta1-adrenergic receptors promote focal adhesion signaling downregulation and myocyte apoptosis in acute volume overload. J Mol Cell Cardiol. 2012;53(2):240-9.

44. Ghosh PM, Shu ZJ, Zhu B, Lu Z, Ikeno Y, Barnes JL. Role of $\beta$-adrenergic receptors in regulation of hepatic fat accumulation during aging. $J$ Endocrinol. 2012:213(3):251-61.

45. Shi Y, Shu ZJ, Xue X, Yeh CK, Katz MS, Kamat A. $\beta 2$-adrenergic receptor ablation modulates hepatic lipid accumulation and glucose tolerance in aging mice. Exp Gerontol. 2016;78:32-8.

46. Spear JF, Prabu SK, Galati D, Raza H, Anandatheerthavarada HK, Avadhani NG. beta1-Adrenoreceptor activation contributes to ischemia-reperfusion damage as well as playing a role in ischemic preconditioning. Am J Physiol Heart Circ Physiol. 2007;292(5):H2459-66.

47. Wang J, Hu X, Xie J, Xu W, Jiang H. Beta-1-adrenergic receptors mediate Nrf2HO-1-HMGB1 axis regulation to attenuate hypoxia/reoxygenation-induced cardiomyocytes injury in vitro. Cell Physiol Biochem. 2015;35(2):767-77.

48. Swift JM, Swift SN, Allen MR, Bloomfield SA. Beta-1 adrenergic agonist treatment mitigates negative changes in cancellous bone microarchitecture and inhibits osteocyte apoptosis during disuse. PLoS One. 2014;9(9):e106904-1-8.

49. Zapater P, Gómez-Hurtado I, Peiró G, González-Navajas JM, García I, Giménez P. Beta-adrenergic receptor 1 selective antagonism inhibits norepinephrine-mediated TNF-alpha downregulation in experimental liver cirrhosis. PLoS One. 2012;7(8):e43371.

\section{Submit your next manuscript to BioMed Central and we will help you at every step:}

- We accept pre-submission inquiries

- Our selector tool helps you to find the most relevant journal

- We provide round the clock customer support

- Convenient online submission

- Thorough peer review

- Inclusion in PubMed and all major indexing services

- Maximum visibility for your research

Submit your manuscript at www.biomedcentral.com/submit
) Biomed Central 